\title{
Sustainability in Corporate Practice Certification Based on DIN and ISO
}

\author{
Georg Sievers \\ University of Economics Bratislava, \\ Faculty of Economy and Management, Slovakia
}

\section{Abstract}

The term sustainability is increasingly evolving as a buzzword and is frequently used in a manner which is different to its original meaning. Building upon the triple bottom line discussion one can however ascertain that the current social, ecological and economic challenges represent fundamental issues for the corporate context. In this manner it is a matter of business sustainability (BST)/ "Corporate Sustainability" (CS) and the significance for "Sustainable Development" (SD) in an enterprise. SD can therefore be an expression of ethical thinking and conduct within an enterprise which means that sustainability should be embedded firmly in corporate strategies and role models and must be the object of all forms of corporate/political decision-making. In this manner a company meets the requirements of so-called sustainability ethics which represents a combination of ethical thoughts and sustainable objectives. In this regard certification in the company based on the German industrial norm (DIN)/ the instructions of the International Standard Organization (ISO) can help to ensure the implementation of sustainability in the company. However, these activities cannot merely be ticking off checklists but must be implemented in the context of the corporate culture.

Keywords: Sustainability, Certification, Ethics, Management, Corporate Management JEL Classification: E10, G30, M12, M20

\section{Introduction}

\section{Sustainability as result of the implementation of sustainable conduct behaviour in companies}

In this chapter an introduction is provided. Following a general introduction of the issue in this chapter (Chapter 1), in chapter 2 certification based on DIN and ISO is analysed within the context of ethics. The article is completed by a conclusion which summarises the significant issues of the topic in a reflective manner (Chapter 3). 
The term sustainability is currently developing (March 2020) increasingly as a buzzword. The current global problems such as the explosion of the population, climate change, resource scarcity, unemployment, increasing gap between rich and poor, exploitation of natural resources and child labour are frequently drivers of this discussion. In addition, we are experiencing the globalisation of the economy, international networks through web 2.0, the financial economic crisis between 2008 and 2010 and change in needs and demands of consumers (Armutat/Mödinger, 2001, p. $14 \mathrm{f}$.). In many cases however the term is used too superficially outside context of its original meaning and focus and in this regard people forget that sustainability nowadays goes way beyond the greenness of products, services or behaviour/corporate cultures/ - to be more precise must go beyond the latter (German Private Institute for sustainability and economy (ed.), 2013a, p. 1 ff.).

Based on a definition of the "Deutschen privaten Instituts für Nachhaltigkeit und Ökonomie" (private German Institute for sustainability and economy) the main idea of sustainability is to be defined as follows: "the sensible linking of ecology, economy and social responsibility only works at corporate level based on economic principles. Because: sustainability is more than green, sustainable commercial value creation ensures long-term competence in terms of ecological and social responsibility." (Deutsches privates Institut für Nachhaltigkeit und Ökonomie ed.), 2013b, p. 1 ff.) This idea/this key notion is implemented through the so-called "three pillar concept of sustainability". In this respect concept includes the ecological, economic and the social dimension of the term (Deutsches privates Institut für Nachhaltigkeit und Ökonomie (ed.), 2013a, p. 1 ff.). In more precise commercial terms it is to be understood as careful use of resources which has a positive effect on the environment and is also cost efficient. In a wider sense sustainability can be understood as a sociopolitical and holistic concept and be marketed to stakeholders, employees, business partners and customers (Pufé, 2012, pp. 6-9). This explanation builds on the so-called "Triple-Bottom-Line-Discussion" of the federal government/the United Nations (UN) and has been applied in the definition of sustainability on the part of the EnqueteCommission of German Parliament dating back to 2004 (Cf. Deutscher Bundestag Enquete-Kommission (ed.), 2013, p. 1 ff.). The Enquete-Commission defines sustainability as a permanently future oriented development of the economic, ecological and social dimension of human existence" (Deutscher Bundestag Enquete-Kommission (ed.), 2013, p. 1 ff.; Bechmann, 1993, pp. 296-305).

According to the German Duden the term sustainability expresses "an effect over a longer period". This means, based on the principle in forestry, that no more wood should be cut down than can be replaced and based on the ecological principle that no more should be consumed than can be provided again in the future (Pufé, 2012, p. 8). In this respect the dimensions of sustainability listed are like a "magic triangle" dependent on one another and influencing one another (Hennicke, 2002, p. $10 \mathrm{ff}$.) and Hennicke for instance recommends portrayal in the form of a house because in his view ecology is to be regarded as a precondition in order to be able to act 
economically or be socially active (Hennicke, 2002, p. 10 ff.; Promberger/Spiess, 2006, p. 10 ff.; Huber, 2002, p. 307). Sustainability was first mentioned in forestry in 1713 by the mine captain Hans Carl von Carlowitz (Pufé, 2012, p. 56). Carlowitz compiled his piece of work Mine Captain Sylvicultura Oeconomica Oder Haußwirthliche Nachricht und Naturmäßige Anweisung zur wilden Baum-Zucht" and referred to "the balance between use of resources and maintaining resources as an economic factor which is more beneficial for corporate actions than exploiting resources Oberberghauptmann (Herzog, 2005, p. 4). This original definition of sustainability already shows that simply referring to the economic aspects in the context of sustainability and the resulting responsibility discussion has developed significantly further. Taken from its historical origins the understanding of sustainability prevailing today can be defined in the context of this paper as follows: "sustainable development is a development which guarantees that future generations are not in a worse position in terms of needs satisfaction than current generations which are still alive:" (Pufe p.14)

This definition can be supplemented by the aspect that the company is required to behave accordingly - expressed in the term "Business Sustainability" (BST) - enabling companies to put sustainability into practice and thus shoulder their social responsibility. The terms "ethics" or "ethical action" and "sustainability" are therefore closely related to each other, thus allowing the term "sustainability ethics" to establish itself as: "The market economy and competition are often declared to be a zone free of morality, from which those who are already better off benefit at the expense of those who are weaker. This prejudice is not correct. The market and competition drive growth, prosperity and social security. They thus significantly contribute to social development, which particularly benefits the less privileged. In addition to this, performance and creativity are rewarded by competition. It therefore establishes the opportunity for broad sections of society to share in the economic success" (Die bayerische Wirtschaft (vbw) (ed.), 2016, n.p.)

Against this backdrop, this paper will examine the issue of how sustainability can be implemented in companies by using DIN and ISO certifications in an ethical context.

\section{Classifying certification per DIN and ISO in the ethical context}

This chapter will discuss the classification of DIN and ISO certification in the ethical context. To do this, a general classification of sustainability in the corporate context will be dealt with first (Chapter 2.1.), then a connection will be made between sustainability in companies and ethical action (Chapter 2.2.) before the application of DIN and ISO standards are finally presented as instruments and aids for its implementation (Chapter 2.3.). 


\subsection{Classifying sustainability in the corporate context}

As already described (cf. Chapter 1), sustainability must be firmly anchored in a company's strategy (i.e. in the mission statement, vision, mission and ultimately also in the management guidelines). This does not only apply against the backdrop of companies needing to comply with corresponding legal requirements, such as meeting the requirements for sustainability reporting or ensuring compliance with international guidelines on sustainability, e.g. those of the UN or the "Organisation for Economic Cooperation and Development" (OECD), but they must also in this context fulfil their social responsibility and their responsibility towards their employees.

Within the framework of its discussion on sustainability by the formulation of the term "sustainable development", this is also required by the EU Commission: "Sustainable Development stands for meeting the needs of present generations without jeopardising the ability of future generations to meet their own needs - in other words, a better quality of life for everyone, now and for generations to come. It offers a vision of progress that integrates immediate and longer-term objectives, local and global action, and regards social, economic and environmental issues as inseparable and interdependent components of human progress. Sustainable development will not be brought about by policies only: it must be taken up by society at large as a principle guiding the many choices each citizen makes every day, as well as the big political and economic decisions that have to be taken. This requires profound changes in thinking, in economic and social structures and in consumption and production patterns." (European Commission (ed.), 2015, n.p.) As formulated by the EU Commission, this requirement means that sustainability is often equated with the development of Corporate Social Responsibility (CSR). Literature, however, at least in part, first 'only' interprets CSR to be an expression of sustainability instead of sustainability per se and has therefore developed the term BST of Corporate Sustainability (CS) for sustainability in the corporate context (Kugler/Olbert-Bock, 2011, p. 18).

It therefore can be stated that when companies assume responsibility, they also meet the requirements for sustainability. At the same time, this should be seen as an opportunity to align a company's business models and processes with valid economic, ecological and social criteria and thus "overcome" the traditional mindset of orientation towards pure profit. To this end, the EU's sustainability strategy defines key fields of action (Federal Ministry for the Environment, Nature Conservation, Building and Nuclear Safety (ed.), 2013, n.p.): climate change and clean energy, the development of sustainable transport, sustainable consumption and production, the protection and management of natural resources, public health, poverty and sustainable development as well as social inclusion, demography and migration (Federal Ministry for the Environment, Nature Conservation, Building and Nuclear Safety (ed.), 2013, n.p.)

If companies take these approaches into account, they can have positive effects on the 
company itself - within the meaning of employee loyalty/employee recruitment, image and thus (ultimately) business success - as well as on the company's entire social environment or each individual employee. It is therefore the core task of every company to (a) be acquainted with the relationships described and to (b) use them positively for itself and its social environment without placing too much emphasis on the possible (previously) exclusive focus on monetary issues. As a result, if both individual components (making profits as a so-called business case) and social components (creating added value for society and individuals as a so-called social case) can be given equal consideration (Leitschuh-Fecht/Steger, 2003, pp. 257-266), sustainability in the corporate context can serve to overcome a dualism between ethics and economics and then to evaluate entrepreneurship as positive.

By not initially focussing on compliance with directives or standards, but instead by presenting measures on how a company can become "Truly Sustainable" (Dyllick/Muff, 2015, p. 1), Dyllick/Muff provide an interesting approach to its implementation. Accordingly, companies must achieve level 3.0 in their sustainability policy to be in order to be considered "Truly Sustainable". To achieve this, companies must embrace sustainability and focus on sustainability guidelines, thereby making a positive contribution to solving global problems (Dyllick/Muff, 2015, p. 14). This can be accomplished, for example, by meeting the requirements of the "Global Reporting Initiative" (GRI). To reach the mentioned stage of "Truly Sustainable", the path to this goal should occur over three stages $(1.0,2.0,3.0)$. The following graphic illustrates what each stage is comprised of, the fields of action and their corresponding characteristics.

The initial situation and the objectives are recorded in the "Concern" phase, the "Values Created" phase is characterised by the creation of (new) (sustainable) values, and the "Organisational Perspective" phase is characterised by the transfer of inner values to society and the corporate field and thus the achievement of the "Truly Sustainable" objectives in the company (Dyllick/Muff, 2015, p. 13). The authors describe this last stage as follows: "Truly sustainable business shifts its perspective from seeking to minimise its negative impacts to understanding how it can create a behavioural positive impact in critical and relevant areas for society and the planet. A Business Sustainability 3.0 firm looks first at the external environment within which it operates and then asks itself what it can do to help overcome critical challenges that demand the resources and competencies it has at its disposal." (Dyllick/Muff, 2015, S. 10 f.) 


\begin{tabular}{|c|c|c|c|}
\hline $\begin{array}{c}\text { BUSINESS SUSTAINABILITY } \\
\text { TYPOLOGY }\end{array}$ & $\begin{array}{l}\text { Concerns } \\
\text { (What?) }\end{array}$ & $\begin{array}{l}\text { Values created } \\
\text { (What for?) }\end{array}$ & $\begin{array}{c}\text { Organizational } \\
\text { perspective } \\
\text { (How?) }\end{array}$ \\
\hline Business-as-usual & Economic concerns & Shareholder value & Inside-out \\
\hline $\begin{array}{l}\text { Business Sustainability 1.0: } \\
\text { Refined Shareholder Value }\end{array}$ & $\begin{array}{l}\text { Three-dimensional } \\
\text { concerns }\end{array}$ & Shareholder value & Inside-out \\
\hline $\begin{array}{l}\text { Business Sustainability 2.0: } \\
\text { Triple Bottom Line }\end{array}$ & $\begin{array}{l}\text { Three-dimensional } \\
\text { concerns }\end{array}$ & Triple bottom line & Inside-out \\
\hline $\begin{array}{l}\text { Business Sustainability 3.0: } \\
\text { True Business Sustainability: }\end{array}$ & $\begin{array}{l}\text { Starting with } \\
\text { sustainability } \\
\text { challenges }\end{array}$ & $\begin{array}{l}\text { Creating value for } \\
\text { the common good }\end{array}$ & Outside-in \\
\hline The key shifts involved: & $\begin{array}{l}1^{\text {st }} \text { shift: } \\
\text { broadening the } \\
\text { business concern }\end{array}$ & $\begin{array}{l}2^{\text {nd }} \text { shift: } \\
\text { expanding the } \\
\text { value created }\end{array}$ & $\begin{array}{l}3^{\text {rd }} \text { shift: changing } \\
\text { the perspective }\end{array}$ \\
\hline
\end{tabular}

Graphic: Sustainability model (stage model) according to Dyllick/Muff Source: Dyllick/Muff, 2015, p. 13

\subsection{Connection between sustainability and corporate activity in an ethical context: sustainability ethics}

If one uses the method described in chapter 2.2. (cf. Chapter 2.2.) based on the observation made by Christen, it becomes apparent that CSR or respectively CS are often built on ethics when sustainability standards are met within companies (Christen, 2011, p. 3; Oermann/Weinert, 2014, p. 63; Schulz/Christen/VogetKleschin/Burger, 2013, pp. 115-133, Christen/Schmidt, 2012, pp. 400-410; Christen/Schmidt, 2012, pp. 400-410). It may be deduced from this that companies have an obligation to act ethically (Christen, 2011, p. 34), which also ultimately corresponds to the answer to Kant's second fundamental issue of philosophy "What should I do?" (Oermann/Weinert, 2014, p. 63). In this context, ethics in the company can be found on the level of the action and the level of orientation in its application as so-called "sustainability ethics" as, according to Christen, ethics can then demonstrate "that the idea of sustainability cannot be comprehended solely on the basis of scientific terminology and methodology, but as an orientation for action based on a genuinely normative foundation" (Christen, 2011, p. 35). Sustainability is therefore not an exclusively descriptive instrument, but instead aims at "regulating the relationship between society and its natural environment" (Christen, 2011, p. 35). In this context, "by introducing justified actions and convictions in decision-making 
situations and by placing expressions of opinion on a meaningful basis of justification" (Oermann/Weinert, 2014, p. 64), ethics also has a function in integration and orientation (Nida-Rümelin, 2017, p. 8), i.e. there is a weighing of different options on how it should be implemented, thus achieving a morally "right" action (Oermann/Weinert, 2014, p. 64 f.).

In this context, sustainability ethics are to be understood as applied ethics and deal "with ethical problems on a cross-generational time axis in the scope of the discourse on sustainability" (Oermann/Weinert, 2014, p. 67) and as an attempt to structure and "provide orientation in specific situations of action" (Oermann/Weinert, 2014, p. 67).

Thus, following Rogall (2008, p. 150), sustainability ethics are to be understood as an "ethical reflection of a definable and implementable inter- and intragenerative principle of justice" (Oermann/Weinert, 2014, p. 69). Hutterer emphasises that sustainable development requires decision-makers to take responsibility for their actions and, as a result, "(...) ethics are an indispensable prerequisite for making sustainable decisions" (Hutterer, 2003, p. 1). The ethical principles of Christianity lie in the pursuit of virtue (e.g. faith, hope, charity) (Michaelis, 2000, n.p.). This can be achieved by implementing the following aspects in entrepreneurial activities (rpi virtuell (ed.), 2002, n.p.; Federal Ministry for Economic Cooperation and Development (BMZ) (ed.), 2016, pp. 1-24):

- interpreting the world as a gift to mankind,

- perceiving the earth as a sensitive organism (a subject, but no object),

- people must "subordinate" themselves to the earth and establish a new relationship with the world,

- life and earth belong together; they are interrelated and interdependent,

- people must serve in the network of life,

- people have a responsibility towards the living and the world.

\subsection{DIN and ISO certifications as implementation measures and assistance}

Certifications must be interpreted and understood from both the perspective of "external confirmations" or "external recognitions" and as a guideline or way to implement sustainability within the company.

By looking primarily at "external confirmation", one often speaks of audits or auditing; in other cases, one speaks of certification or - if repeated accordingly - also of re-certification (so-called initial audits and annual repeat audits). Certifications therefore implicitly contribute to the efforts made within the company to either maintain and/or further develop the achieved standards. The following advantages can therefore go hand in hand with certification (TÜV Rheinland (ed.), n.s., n.p.):

- implementation of sustainability principles and thus confirmation of the company's corresponding (future-oriented) alignment,

- differentiation from the competition, 
- proof of the entrepreneurial action's intrinsic value,

- reinforcement of the competitive position,

- positioning as an attractive employer (sustainability as measure for employer branding),

- indemnification of the verifiability, planning and measurability of sustainability activities,

- improvement of the company image and brand image,

- orientation of the company towards the challenges of the future,

- optimisation of processes and measures concerning risk reduction, risk control and risk prevention.

In accordance with ISO 17065, the certifications to be carried out must be accompanied or implemented externally by approved certification and supervisory authorities (so-called auditing supervisory authorities) and can be realised pursuant to DIN or ISO standards. The certificates are issued by approved issuers, such as EcoControl GmbH in Germany. Within the scope of the audits, the actual situation is recorded by checking the minimum requirements according to DIN or ISO and, as a rule, by formulating - if not yet available - at least three sustainability targets for the company and determining the time-limit for their implementation. The use of indicators must make it possible to check these goals. The certification itself is carried out according to national standards that meet the GRI's environmental standard ISO 14001 and indicators. The CSE seal (which stands for "Certified Sustainable Economics") is one common standard for Germany; current version: CSE Standard 5.0), which is a sustainability seal for certified corporate management and - in contrast to product certifications - tests sustainability throughout the entire company: "It [the CSE seal, author's note] stands for responsible business decisions that are made in harmony with all corporate environments. The three dimensions of sustainability - ecology, social responsibility and economy - are equally important core competencies for these companies and continuously optimised. The CSE standard satisfies the environmental standard (ISO 14001) and includes the indicators are checked according to GRI (Global Report Initiative). Companies that have been certified in accordance with the CSE standard are allowed to label their products with the CSE seal". (Society for Applied Business Ethics (GfaW) (eds.), 2016a, n.p.; Society for Applied Business Ethics (GfaW) (eds.), 2016b, pp. 1-20; Trajer, 2007, pp. 1 ff.)

ISO 14001 requires companies to take action in the following fields (Gesellschaft für angewandte Wirtschaftsethik (GfaW) (eds.), 2016c, p. 1-13):

- context of the organisation, understanding the context of the organisation, understanding the needs and expectations of interested parties, defining the scope of the (environmental management) system,

- environmental policy, environmental aspects, setting environmental objectives and plans to achieve them, 
- planning, binding obligations, action planning, measures to deal with risks, operational planning and governance, emergency provision and danger prevention,

- leadership and commitment, roles and responsibilities, authorities, resources, competencies, awareness.

Although DIN does not - as with the ISO standard - focus on ethics as a key issue, the relevant DIN standard (DIN ISO 26000, November 2011 edition) calls for a guide to social responsibility. In line with DIN, sustainability is understood as a commitment, as a living culture of values, to act responsibly and is expressed in the following aspects:

- the relationship between corporate characteristics and social responsibility,

- evaluation and optimisation of activities and approaches to the implementation of ethical principles ("good action"),

- continuous observation and monitoring of an activity (so-called monitoring),

- communication of social responsibility (values, application of principles), internally and externally,

- supporting initiatives for social responsibility.

The fulfilment of these aspects should serve to address the core areas of ethical action according to DIN. These deal with fair ("honest") working, operating and business practices as well as the identification and involvement of stakeholder groups (Gehlen, 2012, p. 1). To this end, the DIN Institute has developed a guide to implementation, which is divided into four sections: "Corporate Ethics", "Corporate Governance", "Corporate Citizenship" and "Ethical Concerns of the Auditor" (Berner/Dettmann/Kohlhoff, 2006, p. 1 ff.), thus incorporating the seven sections of ISO 26000, with section 4, the seven principles of social responsibility, of particular relevance (e.g. ethical conduct is explicitly mentioned here in point 3 ).

The following graphic shows an overview of ISO 26000 and the regulations contained therein. 


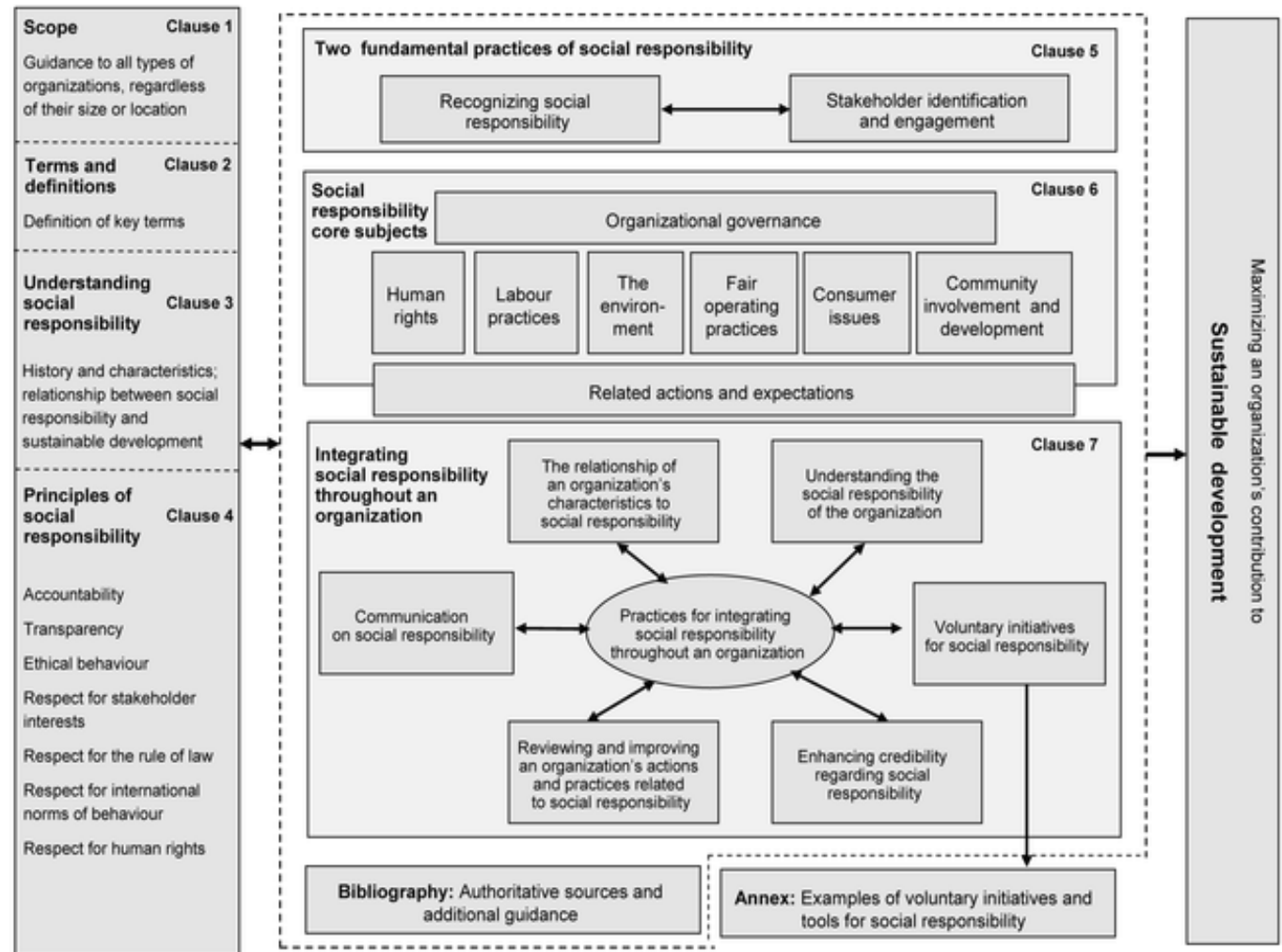

Graphic: Schematic overview of ISO 26000

Source: iso.org (ed.), 2010, Figure 1

It should be noted here that the German implementation of ISO in the form of DIN ISO 26000 is not a certifiable management standard, as is possible with ISO 9001 or ISO 140001, for example: "This International Standard is not a management system standard. It is not intended or appropriate for certification purposes or regulatory or contractual use. Any offer to certify, or claims to be certified, to ISO 26000 would be a misrepresentation of the intent and purpose and a misuse of this International Standard. As this International Standard does not contain requirements, any such certification would not be a demonstration of conformity with this International Standard." (iso.org (ed.), 2010, document N191)

\section{Conclusion}

This chapter will present the main conclusions that can be drawn from considering sustainability, certification and ethics in the context presented.

This paper examined the role of sustainability ethics in companies and how they can be interpreted as the realisation of corporate aspects in the corporate context. It demonstrated that DIN and ISO certifications can be understood as framework 
conditions or paths to sustainability in companies. The final conclusion here is that (corporate) ethics are an indispensable prerequisite for making sustainable decisions.

The key aspects of this paper can be summarised in the following propositions:

Proposition 1: Sustainability within the company is reflected in the compatibility of ecological, economic and social aspects. In some cases, the consideration of ecological aspects is considered here a prerequisite for achieving the economic and social aspects.

Proposition 2: A permanent implementation of sustainability ethics in companies can be ensured or initiated using certification. For example, companies can set themselves apart from the competition, fundamentally orient themselves towards sustainability and thereby strengthen their competitive positions.

Proposition 3: Companies use sustainable activities to do justice to their social and societal mission, while at the same time presenting themselves as attractive employers.

Proposition 4: The term "business sustainability" or "corporate sustainability" has become established in the sustainability context for companies. These terms represent an expression for sustainability - sustainability ethics in the context of the level of action and application-orientation - and not for sustainability per se, i.e. the assumption of responsibility results in companies meeting the demand for sustainability.

Proposition 5: A company must aim at becoming "Truly Sustainable", which can notably be achieved by integrating activities for sustainability into the company organisation (structural and process organisation).

Proposition 6: Certification can be obtained via ISO 14001 or, in Germany, DIN ISO 26000, even though DIN 26000 itself cannot be certified as a management system. Equivalent standards, such as the CSE standard or the specifications of the Global Reporting Initiative, must therefore be used.

\section{References}

[1] Armutat, S. - Mödinger, W. (2001): Nachhaltigkeit - Ressourcenbalance als Schlüsselprinzip (nicht nur) im 21. Jahrhundert. In DGFP e.V. (ed.), Personalmanagement nachhaltig gestalten - Anforderungen und Handlungshilfen, DGFP PraxisEdition, Band 99. Bielefeld/Düsseldorf, Eigenverlag, pp. 14-17. ISBN 978-3-7639-3863-6

[2] Bechmann, G. (1993). Ethische Grenzen der Technik oder technische Grenzen der Ethik? Geschichte und Gegenwart, Vierteljahreshefte für Zeitgeschichte, Gesellschaftsanalyse und politische Bildung, 4 (12), 296-305.

[3] Berner, C. - Dettmann, U. - Kohlhof, J. (2006). Ethik im Unternehmen: Leitfaden für die ethische Auditierung nachhaltigen Wirtschaftens. Berlin: Beuth. ISBN 


\section{8-3-410-16419-7}

[4] Bundesministerium für wirtschaftliche Zusammenarbeit und Entwicklung (BMZ) (ed.) (2016). Partner für den Wandel: Religionen und nachhaltige Entwicklung.

https://www.bmz.de/de/mediathek/publikationen/reihen/weitere_materi alien/Auszug_religionen_nachhaltige_entwicklung.pdf [accessed 4.3.2020].

[5] Christen, M. - Schmidt, S. (2012). A formal framework for conceptions of sustainability - a theoretical contribution to the discourse in sustainable development. In Sustainable Development, 20(6), pp. 400-410.

[6] Christen, M. (2009). Die Wertebasis starker Nachhaltigkeit - Eine Untersuchung der axiologischen Grundlagen des Greifswalder Ansatzes. In von Egan-Krieger, T. - Schulz, J. - Thapa, P.P. - Voget, L. (ed.), Die Greifswalder Theorie starker Nachhaltigkeit: Ausbau, Anwendung und Kritik. Berlin: Metropolis, pp. 125-141. ISBN 978-3895187506

[7] Christen, M. (2011): Nachhaltigkeit als ethische Herausforderung: Marius Christen über den Greifswalder Ansatz von Konrad Ott und Ralf Döring. In Information Philosophie, 2, pp. 34-43.

[8] Deutscher Bundestag - Enquete-Kommission (ed.) (2013). Wachstum Wohlstand - Lebensqualität: Wege zu nachhaltigem Wirtschaften und gesellschaftlichem Fortschritt in der sozialen Marktwirtschaft. Berlin: Eigenverlag.

[9] Deutsches privates Institut für Nachhaltigkeit und Ökonomie (ed.) (2013a). Definition Nachhaltigkeit. http://www.di-no.eu/nachhaltigkeit-was-istdas.html, [accessed 4.3.2020].

[10] Deutsches privates Institut für Nachhaltigkeit und Ökonomie (ed.) (2013b). Leitgedanke. http://www.di-no.eu/wir-ueber-uns.html, [accessed 4.3.2020].

[11] Die bayerische Wirtschaft (vbw) (ed.) (2016). Position: Nachhaltigkeit und Ethik in der Wirtschaft. https://www.vbwbayern.de/vbw/Aktionsfelder/Wirtschaft-und-

Gesellschaft/Nachhaltigkeit/Nachhaltigkeit-und-Ethik-in-der-Wirtschaft.jsp, [accessed 4.3.2020].

[12] Dyllick, T. - Muff, K. (2015). Clarifying the Meaning of Sustainable Business: Introducing a Typology From Business-as-Usual to True Business Sustainability. In Organization \& Environment, 28 (1), pp. 1-19.

[13] European Commission (ed.) (2015). Sustainable Development. http://ec.europa.eu/environment/eussd/, [accessed 4.3.2020].

[14] Gehlen, R. (2012). Ethik in Unternehmen nach DIN ISO 26000 Leitfaden zur gesellschaftlichen Verantwortung. http://moraviaverlag.de/html/verlag/SchaubildEthik_Mod.pdf, [accessed 4.3.2020].

[15] Gesellschaft für angewandte Wirtschaftsethik (GfaW) (ed.) (2016a). CSEStandard 5.0: Der Qualitätsstandard zur Zertifizierung nachhaltiger Unternehmensführung. http://angewandte-wirtschaftsethik.org/wpcontent/uploads/2012/03/CSE-Standard-5.0.pdf, [accessed 4.3.2020]. 
[16] Gesellschaft für angewandte Wirtschaftsethik (GfaW) (ed.) (2016c). Überschneidungen des CSE 5.0 Standards mit ISO 14001 und Gemeinwohlökonomie. http://angewandte-wirtschaftsethik.org/wpcontent/uploads/2012/03/Synopse-CSE-5.0-zu-ISO-14001-undGW\%C3\%96.pdf [accessed 4.3.2020].

[17] Gesellschaft für angewandte Wirtschaftsethik (GfaW) (ed.) (2016b). CSE. http://angewandte-wirtschaftsethik.org/der-cse-standard/ [accessed 4.3.2020].

[18] Herzog, T. (2005). Nachhaltigkeit. München: Hanser.

[19] Huber, W. (2002). Sozialethik als Verantwortungsethik. In Honecker, M. (ed.), Einführung in die theologische Ethik: Grundlagen und Grundbegriffe. Berlin: de Gruyter, p. 337. ISBN 978-3110176346

[20] Hutter, H. (2003). Ethik und Nachhaltige Entwicklung. Wien: Eigenverlag.

[21] iso.org (Ed.) (2010): ISO 26000:2010 (en) - Guidance on social responsibility. https://www.iso.org/obp/ui/\#iso:std:iso:26000:ed-1:v1:en, [accessed 4.3.2020].

[22] Kugler, P. - Olbert-Bock, S. (2011). Nachhaltige Unternehmensentwicklung (1/3): Zielkonflikte als zentrale Herausforderung. KMU-Magazin, 10 (9), pp. $18-24$.

[23] Leitschuh-Fecht, H. - Steger, U. (2003). Wie wird Nachhaltigkeit für Unternehmen attraktiv? Business Case für nachhaltige Unternehmensentwicklung. In Linne, G. - Schwarz, M. (ed.), Handbuch Nachhaltige Entwicklung. Wiesbaden: VS Verlag für Sozialwissenschaften, pp. 257-266. ISBN 978-3810037589

[24] Michaelis, L. (2000). Ethics of Consumption. Oxford: Oxford Centre for the Environment, Ethics \& Society.

[25] Nieda-Rümelin, J. (2017). Über Grenzen denken: Eine Ethik der Migration. Hamburg: Edition Körber-Stiftung. ISBN 978-3896841957

[26] Oermann, N.O. - Weinert, A. (2014). Nachhaltigkeitsethik. In Heinrichs, H. Michelsen, G. (ed.), Nachhaltigkeitswissenschaften. Berlin/Heidelberg: Springer, pp. 63-72.

[27] Promberger, K. - Spiees, H. (2006). Der Einfluss von Corporate Social (and Ecological) Responsibility auf den Unternehmenserfolg. Working Paper, 26/2006. Innsbruck: Universität Innsbruck, Institut für Strategisches Management, Marketing und Tourismus - Arbeitsbereich für Verwaltungsmanagement.

[28] Pufé, I. (2012). Nachhaltigkeitsmanagement. München: Hanser. ISBN 9783446430204

[29] Rogall, H. (2008). Ökologische Ökonomie - Eine Einführung. 2., überarbeitete und erweiterte Auflage. Wiesbaden: Springer VS. ISBN 978-3531910017

[30] rpi virtuell (ed.) (2002). Seminar Nachhaltigkeit im Dialog der Weltreligionen. http://www.rpivirtuell.net/material/search/query/tag:\%22Nachhaltigkeit\%22\#0 
[accessed 4.3.2020].

[31] Schultz, E. - Christen, M. - Voget-Kleschin, L. - Burger, P. (2013). A Sustainability-fitting Interpretation of the Capabilities Approach: Integrating the Natural Dimension by employing Feedback Loops. In Journal of Human Development and Capabilities, 14 (1), pp. 115-133.

[32] Trajer, J. (2007). Auditierung/Zertifizierung im Personalbereich - Theoretische Erkenntnisse und empirische Befunde. Hamburg: GRIN. ISBN 978-3640964963

[33] TÜV Rheinland (ed.) (o.J.). Zertifikat für nachhaltige Unternehmensführung. https://www.tuv.com/germany/de/zertifikat-f\%C3\%BCr-nachhaltigeunternehmensf\%C3\%BChrung.html [accessed 4.3.2020]. 